\title{
On-site rapid detection of toxic Alexandrium tamiyavanichii: integrating the species-specific hydrolysis probe in insulated isothermal polymerase chain reaction (iiPCR)
}

\author{
Nyuk Fong Kon ${ }^{1}$ - Winnie Lik Sing Lau ${ }^{2}$ Ing Kuo Law ${ }^{2}$ Po Teen Lim² \\ Chui Pin Leaw ${ }^{2}$
}

Received: 17 September 2015 / Revised and accepted: 19 January 2016

(C) Springer Science+Business Media Dordrecht 2016

\begin{abstract}
On-site investigation of phytoplankton samples is important for rapid detection of harmful algal species and for early warning of harmful algal bloom. Molecular detection method by DNA amplification in a portable insulated isothermal PCR (iiPCR) device provides a simple and rapid detection based on fluorescent probe within an hour of reaction time. The assay was developed for a paralytic shellfish toxinproducing dinoflagellate Alexandrium tamiyavanichii. The assay presents the data as positive or negative on the presence or absence of $A$. tamiyavanichii cells, with a limit of detection (LOD) at five target cells per reaction. While the assay is incapable to accurately quantify cell density, it exhibits high detection accuracy and strongly correlated with quantitative PCR (qPCR) data. The user repeatability of iiPCR assay was evaluated; the results showed that no significant differences in the assay run by different operators. Field applicability of the assay was further validated by environmental samples. Despite the shortcoming of the assay, the overall performance of the assay to detect cells, its low-cost effectiveness, and portability for on-site detection, iiPCR has proven its potential as an early screening tool for harmful algae monitoring.
\end{abstract}

Keywords Alexandrium · Dinoflagellate $\cdot$ Insulated isothermal polymerase chain reaction (iiPCR) $\cdot$ Internal transcribed spacer (ITS) $\cdot$ Paralytic shellfish poisoning $\cdot$ Rapid molecular detection

Chui Pin Leaw

cpleaw@um.edu.my; chuipinleaw@gmail.com

1 Institute of Biodiversity and Environmental Conservation, Universiti Malaysia Sarawak, 94300 Kota Samarahan, Sarawak, Malaysia

2 Institute of Ocean and Earth Sciences, University of Malaya, 16310 Bachok, Kelantan, Malaysia

\section{Introduction}

The occurrence of paralytic shellfish toxin (PST)-producing dinoflagellate, Alexandrium tamiyavanichii, is one of the main paralytic shellfish poisoning (PSP) causative species in the genus Alexandrium, with relatively high intracellular toxin concentrations as compared to other toxigenic Alexandrium species [e.g., $<180 \mathrm{fmol}^{\mathrm{PST}}$ cell $^{-1}$ from a Malaysian strain of A. tamiyavanichii (Lim et al. 2006)]. The species was originally described by Balech (1967) from the Bay of Mexico. It was later increasingly reported from the waters of Asian Pacific and Atlantic. Its occurrence in the Gulf of Thailand has been attributed to PSP and human fatality (Kodama et al. 1988). The species was also reported from Manila Bay, Philippines (Montojo et al. 2003), Hiroshima, Japan (Beppu et al. 2008), and north eastern Brazil (Menezes et al. 2010). The presence of $A$. tamiyavanichii in Malaysian waters has been well documented (Usup et al. 2002; Lim et al. 2006). The species was responsible for the PSP event in 1991 in the Straits of Malacca (Usup et al. 2002). The species has been shown to be endemic in the south-eastern South China Sea. The species has been found distributed along the coasts of Malaysian Borneo; cell density up to 150 cells $\mathrm{L}^{-1}$ has been detected offshore of southern Borneo (Kon et al. 2015). However, outbreak of PSP was not recorded from this water.

Molecular diagnostic technique has become pivotal in the monitoring of harmful algal species; it replaces the traditional microscopic identification method which is time-consuming and laborious. Various molecular assays are available and have been developed to identify species of Alexandrium, such as the real-time quantitative PCR (qPCR) (Galluzzi et al. 2004; 2010; Hosoi-Tanabe and Sako 2005; Dyhrman et al. 2006), DNA microarray technology (Gescher et al. 2008; Medlin et al. 2013), loop-mediated isothermal amplification method (LAMP) (Nagai and Itakura 2012; Nagai 2013), and 